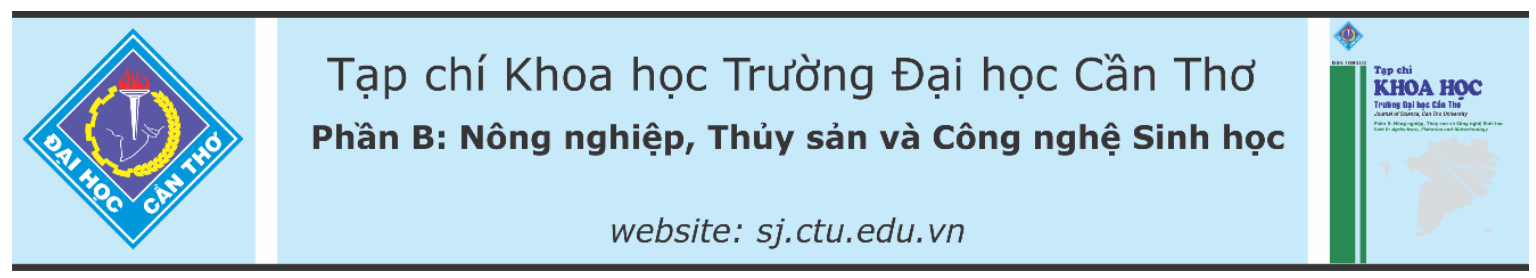

DOI:10.22144/ctu.jvn.2021.018

\title{
PHÂN LẬP VÀ TUYỂ CHỌN MỘT SỐ DÒNG VI KHUẨN TÙ̉ HẠT NGŨ CỐC LÊN MEN CÓ KHẢ NĂNG ĐỐI KHÁNG VỚI NẤM Rhizoctonia solani GÂY BÊNH CHẾT CÂY CON TRÊN ỚT (Capsicum annuum L.) TRONG ĐIỀU KIẸN in vitro
}

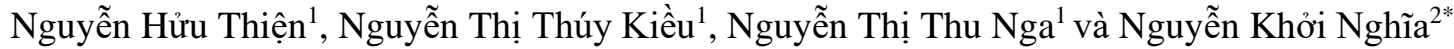 \\ ${ }^{1}$ Bộ môn Bảo vệ thưc vật, Khoa Nông nghiệp, Trương Đại học Cần Tho \\ ${ }^{2}$ Bộ môn Khoa học đất, Khoa Nông nghiệp, Truờng Đại học Cần Tho \\ *Người chịu trách nhiệm bài viết: Nguyễn Khởi Nghĩa (email: nknghia@ctu.edu.vn)
}

\section{Thông tin chung:}

Ngày nhận bài: 04/08/2020

Ngày nhận bài sủa: $31 / 10 / 2020$

Ngày duyệt đăng: 27/02/2021

\section{Title:}

Isolation and selection of bacteria from various fermented cereal grains being capable of antifungal activity against Rhizoctonia solani on chilli (Capsicum annuum L.) in vitro condition

\section{Tù khóa:}

Bacillus velezensis, chết gục cây con, hạt ngũ cốc, hoạt tính chống nấm, Rhizoctonia solani

\section{Keywords:}

Antagonistic, Bacillus velezensis, cereal grain, damping-off, Rhizoctonia solani

\section{ABSTRACT}

The study was to find out strains of bacteria isolated from fermented cereal grains, including rice, corn, soybean and sesame, on De Man, Rogosa and Sharpe (MRS) agar medium capable of antagonistic ability to Rhizoctonia solani fungus causing damping-off on chilli seedlings (Capsicum annuum L.). The capability of bacterial isolates against pathogenic fungus was investigated on PDA medium with 4 different experimental conditions including: (1) antagonistic bacteria and pathogenic fungus were inoculated simultaneously, (2) using extracellular fluids of antagonistic bacteria, (3) pathogenic fungus was inoculated 24 hours ahead, and (4) antagonistic bacteria were inoculated 24 hours ahead. The results showed that a total of 33 bacterial isolates were obtained from 4 cereal grains, including 11 strains from rice, 14 strains from corn, 4 strains from soybean, and 4 strains from sesame. Among bacterial isolates, the three strains M2, M3 and G5 had the greatest antagonistic performance with the mycelium growth of the $R$. solani fungus. The isolate G5 showed the greatest antagonistic effectivness under the conditions of which this strain was inoculated 24 hours before Rhizoctonia solani fungus. The strain of bacteria $G 5$ was identified as Bacillus velezensis. G5 by sequencing the 16S-rRNA gene (primers 27F-1492R). The results allow to conclude that fermented cereal grains, particularly fermented rice grains, contain microbial sources of Bacillus spp. being capable of bio-controlling the damping-off on chilli seedlings.

\section{TÓM TẮT}

Nghiên cứu nhằm tìm ra dòng vi khuẩn đối kháng tốt với nấm Rhizoctonia solani gây bệnh chết gục cây con trên ớt được phân lập tù 4 hạt ngũ cốc gồm gạo, bắp, đậu nành và mè lên men trên môi trường De Man, Rogosa and Sharpe (MRS) agar. Thi nghiệm khảo sát khả năng đối kháng được thực hiện trên môi truoơng PDA với 4 phuơng pháp bố tri gồm: (1) vi khuẩn đối kháng và nấm bệnh được đặt vào đĩa Petri cùng lúc; (2) sử dụng dịch ngoại bào của vi khuẩn; (3) nấm được đặt truớc vi khuẩn 24 giờ và (4) vi khuẩn được đặt truớc nấm 24 giờ. Tổng cộng 33 dòng vi khuẩn được phân lập tù 4 loại hạt ngũ cốc với 11, 14, 4 và 4 dòng lần luoọt tù̀ gạo, bắp, đậu nành và mè, trong đó 3 dòng vi khuẩn $M 2, M 3$ và G5 có hiệu suất đối kháng tốt với khuẩn ty nấm $\underline{R}$. solani. Ngoài ra, dòng G5 thể hiện hiệu suất đối kháng với nấm $\underline{R}$ solani tốt nhất khi vi khuẩn được đặt trước nấm 24 giờ. Kết quả giải trình tụ đoạn gen 16S-rRNA (vói cặp mồi 27F-1492R) của dòng G5 cho thấy thuộc loài Bacillus velezensis G5. Tóm lại, có thể thấy rằng hạt gạo lên men có chứa nguồn vi khuẩn Bacillus spp. có khả năng ức chế tốt nấm $\underline{R}$ solani gây bệnh chết gục cây con trên ớt. 


\section{1. ĐẶT VẤN ĐỀ}

Cây ớt (Capsicum sp.) thuộc họ cà (Solanaceae) là loại rau gia vị được trồng phổ biến ở vùng Đồng bằng sông Cửu Long, là cây rau ăn trái có giá trị cao ở thị trường trong nước và xuất khẩu (Mai Thị Phương Anh và ctv., 1996). Bên cạnh nguồn dinh dưỡng dồi dào như vitamin $\mathrm{A}, \mathrm{C}, \mathrm{B}_{1}, \mathrm{~B}_{2} \ldots$, trái ớt còn chứa các hợp chất chống oxy hóa như Capsaicine $\left(\mathrm{C}_{18} \mathrm{H}_{27} \mathrm{NO}_{3}\right)$, là một chất có vị cay giúp tạo cảm giác ngon miệng khi ăn và kích thích quá trình tiêu hóa (Mai Thị Phương Anh và ctv., 1996). Cũng như nhiều loại cây trồng khác, chất lượng và sản lượng ớt bị đe dọa nghiêm trọng bởi các loại bệnh hại, trong đó có bệnh chết gục cây con do nấm Rhizoctonia solani gây ra là bệnh gây hại quan trọng do mầm bệnh có thể xâm nhiễm và gây hại trong suốt quá trình sinh trưởng của cây (Pernezny and Momol, 2006). Tuy nhiên, việc sử dụng thuốc hóa học liên tục trong thời gian dài để phòng trừ bệnh hại sẽ làm mầm bệnh dễ hình thành tính kháng, dễ phát sinh loài mới, gây ô nhiễm môi trường, mất cân bằng hệ sinh thái nông nghiệp, đồng thời còn gây ra hiện tượng lưu tồn các hóa chất độc hại trong nông sản gây ảnh hưởng đến sức khỏe người tiêu dùng (Trần Ánh Lụa, 2016). Biện pháp phòng trừ sinh học dựa trên sự vận dụng các tương tác của vi sinh vật với nhau, để phát huy vai trò của vi sinh vật có lợi có khả năng kiểm soát các tác nhân gây bệnh thông qua các cơ chế như tiết kháng sinh hay gián tiếp kích thích tính kháng bệnh cây trồng để ức chế sự phát triển của mầm bệnh, đây là hướng phát triển bền vững trong sản xuất nông nghiệp trong tương lai do những ưu điểm của chúng như thân thiện và an toàn với môi trường (Silva et al., 2004; Agrios, 2005). Một số nghiên cứu ở Việt Nam trong việc áp dụng vi sinh vật đối kháng để phòng trừ sinh học bệnh đối với nấm $R$. solani gây ra được ghi nhận, điển hình như nghiên cứu của Lưu Thế Hùng (2014) cho thấy chủng Bacillus amyloliquefaciens có khả năng quản lý tốt bệnh đốm vằn trên lúa do nấm $R$. solani với hiệu quả giảm bệnh đạt 47,6\% trong điều kiện nhà lưới, hay nghiên cứu của Ngô Thị Kim Ngân (2014) cho thấy hai chủng xạ khuẩn KS-ST $\mathrm{S}_{6 \mathrm{~b}}$ và $\mathrm{TO}-\mathrm{VL}_{11 \mathrm{~d}}$ với hiệu suất đối kháng trong điều kiện phòng thí nghiệm lần lượt là $59,6 \%$ và $60,8 \%$. Tuy nhiên, các nghiên cứu nhằm phòng trừ nấm $R$. solani gây bệnh chết gục cây con trên cây ớt bằng tác nhân sinh học phần lớn chỉ tập trung khai thác nhóm vi sinh vật ở khu vực vùng rễ của cây trồng (PGPR) mà ít quan tâm đển các cộng đồng vi sinh vật khác. Bên cạnh đó, trong các nghiên cứu trước đây, Tohno et al. (2013) cho thấy trong thời gian lên men hạt gạo, một số loài vi khuẩn có khả năng tiết ra các hợp chất ức chế vi sinh vật gây hại như bacteriocin, bacilyxin, chlotetaine, iturin A, mycobacillin, bacillomycin,... Do đó, nghiên cứu này được thực hiện nhằm mục tiêu phân lập và tuyển chọn một số dòng vi khuẩn từ một số hạt ngũ cốc lên men như hạt gạo, bắp, đậu nành và mè có khả năng đối kháng với nấm $R$. solani gây bệnh chết gục cây con trên cây ớt nhằm đa dạng tác nhân phòng trừ sinh học trong việc quản lý bệnh cây trồng, giúp giảm thiểu ô nhiễm môi trường do hóa chất bảo vệ thực vật gây ra.

\section{PHƯƠNG TIÊN VÀ PHƯƠNG PHÁP NGHIÊN CÚU}

\subsection{Phương tiện}

Nguồn nấm bệnh Rhizoctonia solani được cung cấp từ Bộ môn Bảo vệ thực vật, Khoa Nông nghiệp, Trường Đại học Cần Thơ, được phân lập từ cây ớt bị nhiễm bệnh chết cây con có độc tính gây bệnh cao. Hạt gạo lức, bắp, đậu nành, mè và sữa tươi tiệt trùng của công ty cổ phần sữa Vinamilk Việt Nam.

\subsection{Phương pháp nghiên cứu}

2.2.1. Phân lập và tuyển chọn một số dòng vi khuẩn tù 4 loại hạt ngũ cốc lên men gồm gạo, bắp, đậu nành và mè

Thí nghiệm phân lập và tuyển chọn một số dòng vi khuẩn từ 4 loại hạt ngũ cốc lên men được thực hiện theo phương pháp của Võ Thị Lệ Trinh (2018).

Xử lý mẫu: hạt ngũ cốc được tiệt trùng bề mặt vỏ bên ngoài bằng cách ngâm từng mẫu hạt với cồn $70^{\circ}$ trong 3 phút, sau đó ngâm tiếp với $\mathrm{NaClO}$ và $\mathrm{H}_{2} \mathrm{O}_{2} 3 \%$ trong 3 phút cho mỗi dung dịch. Cuối cùng ngâm và rửa hạt ngũ cốc lại 3 lần với nước cất đã tiệt trùng. Tiến hành ngâm các mẫu hạt ngũ cốc đã tiệt trùng riêng biệt với nước cất tiệt trùng trong bình tam giác $500 \mathrm{~mL}$ theo tỉ lệ 1 hạt : 3 nước (w/v), đậy kín bằng nút gòn tiệt trùng, để yên trong tối ở điểu kiện phòng thí nghiệm 4 ngày. Khi đó dung dịch lên men hạt ngũ cốc có mùi chua, tiến hành thu dung dịch nước chứa vi khuẩn nằm phía bên trên ngũ cốc cho vào sữa tươi chứa trong bình tam giác $500 \mathrm{~mL}$ với tỉ lệ 1 dung dịch : 10 sữa (v/v), sau đó đậy kín bằng nút gòn tiệt trùng, để yên ở nơi thoáng mát và tránh ánh nắng mặt trời trong 4 ngày, khi đó môi trường nuôi đã tách lớp và có mùi chua ngọt. Phân lập: Thu hoạch phần dung dịch nằm dưới lớp sinh khối rắn như là nguồn vi khuẩn của 4 loại ngũ cốc. Tiến hành pha loãng dung dịch chứa vi khuẩn của 4 hệ vi khuẩn từ hạt gạo, bắp, đậu nành và mè với hệ số pha loãng 10 . Hút $0,05 \mathrm{~mL}$ từng nồng độ nhỏ lên trên đĩa Petri chứa môi trường De Man, Rogosa and Sharpe (MRS) agar, trong $1 \mathrm{~L}$ môi trường gồm: 10 
gram Proteose pepton; $10 \mathrm{~g}$ Beef Extract; $5 \mathrm{~g}$ Yeast Extract, $20 \mathrm{~g}$ Glucose, $2 \mathrm{~g}$ Di-potassium hydrogen phosphate, $5 \mathrm{~g}$ Sodium acetate, $2 \mathrm{~g}$ Di-amonium citrate, $0,2 \mathrm{~g}$ Magnesium Sulphate, 0,05 g Manganous Sulphate, $1 \mathrm{~g}$ Tween 80 và $12 \mathrm{~g}$ Agar. Dùng que chà trải đều vi khuẩn trên bề mặt môi trường, sau đó các đĩa Petri chứa mẫu được đặt trong tủ ủ ơ $37^{\circ} \mathrm{C}$ trong 48 giờ. Tiến hành công đoạn tách ròng và làm thuần các dòng vi khuẩn hiện diện trên môi trường MRS agar sau 4 ngày ủ bằng môi trường Tryptone Soybean Agar (TSA) (thành phần trong 1 L môi trường TSA chứa $17 \mathrm{~g}$ Tryptone; $3 \mathrm{~g}$ Papaic digest soybean meal; 2,5 g Glucose; 2,5 g Dipotassium phosphate; $5 \mathrm{~g}$ Sodium chloride và 15 g Agar) trong 5 lần liên tục sau đó quan sát và mô tả hình thái khuẩn lạc, nhuộm Gram và mô tả hình thái tế bào vi khuẩn sau khi các dòng vi khuẩn được tách ròng và làm tinh sạch (John et al., 1994).

2.2.2. Khảo sát khả năng úc chế của các dòng vi khuẩn phân lập lên sự phát triển khuẩn ty của nấm Rhizoctonia solani trong điều kiện in vitro

* Chuẩn bị nấm: Nấm R. solani được nuôi cấy trên môi trường Potato Dextrose Agar (PDA) của công ty HiMedia, trong $1 \mathrm{~L}$ môi trường chứa $200 \mathrm{~g}$ khoai tây; $20 \mathrm{~g}$ Dextrose và $15 \mathrm{~g}$ Agar 2 ngày trước thời gian bố trí thí nghiệm. Sau đó, dùng pasteur pipette thủy tinh có đường kính $6 \mathrm{~mm}$ đề cắt thành các khối agar có chứa sợi nấm phát triển.

* Chuẩn bị vi khuẩn: Khuẩn lạc của các dòng vi khuẩn phân lập tinh sạch sau khi ria trên môi trường được nuôi tăng sinh trong $30 \mathrm{~mL}$ môi trường TSB tiệt trùng và lắc với tốc độ 120 vòng/phút trên máy lắc ngang GFL 3018 trong 2 ngày dưới điều kiện phòng thí nghiệm $\left(28 \pm 2^{\circ} \mathrm{C}\right)$. Tiến hành thu sinh khối vi khuẩn bằng cách ly tâm dung dịch đã được tăng sinh trước đó với tốc độ 6.000 vòng/phút trong 10 phút trên máy ly tâm Mikro 220R. Sau khi ly tâm cho phần dung dịch trong ở trên sang ống falcon vô trùng khác (dung dịch này được xem như dịch ngoại bào để tiến hành bố trí thí nghiệm khảo sát khả năng đối kháng bằng cách sử dụng dịch ngoại bào của vi khuẩn). Tiến hành hiệu chỉnh mật số vi khuẩn sau khi ly tâm về $10^{7} \mathrm{CFU} / \mathrm{mL}$ bằng nước cất tiệt trùng thông qua việc kiểm tra mật số vi khuẩn bằng phương pháp nhỏ giọt (Hoben and Somasegaran, 1982).

* Bố trí thí nghiệm: Việc khảo sát khả năng đối kháng của các dòng vi khuẩn phân lập với nấm $R$. solani được thực hiện theo phương pháp của Denis and Webster (1971). Thí nghiệm được thực hiện trên môi trường PDA với 3 lần lặp lại cho mỗi chủng vi khuẩn và nấm. Thực hiện đặt khoanh khuẩn ty nấm
$R$. solani có đường kính $6 \mathrm{~mm}$ vào vị trí chính giữa đĩa Petri có chứa môi trường PDA, tiếp theo đặt khoanh giấy lọc có đường kính $1 \mathrm{~cm}$ đã được tẩm huyền phù vi khuẩn $\left(10^{7} \mathrm{CFU} / \mathrm{mL}\right)$ lên bề mặt môi trường tại 3 vị trí liên tục nhau tương ứng với 3 dòng vi khuẩn khác nhau (cách thành đĩa Petri $1 \mathrm{~cm}$ ) và vị trí còn lại đặt mẫu đối chứng với khoanh giấy lọc được tẩm nước cất tiệt trùng, để trong 1 phút tiến hành gấp giấy lọc ra khỏi đĩa Petri (Hình 1). Đặt các đĩa chứa mẫu vào tủ ủ ở nhiệt độ $\left(28 \pm 2^{\circ} \mathrm{C}\right)$ và ghi nhận khả năng đối kháng ở các thời điểm $3,5,7$ và 9 ngày sau bố trí (thời điểm khuẩn ty nấm mọc về phía đối chứng chạm thành đĩa Petri) và tính phần trăm đối kháng (hay còn gọi là hiệu suất đối kháng) theo công thức (1).

Phần trăm đối kháng của vi khuẩn (Percent inhibition - PI) được tính theo công thức Abbott (được trích dẫn bởi Phạm Văn Biên và ctv., 2005) sau:

$$
P I=(R-r) / R \times 100(1)
$$

Trong đó: PI: phần trăm đối kháng của vi khuẩn

R: bán kính khuẩn ty của dòng nấm gây bệnh về phía đối chứng $(\mathrm{mm})$

r: bán kính khuẩn ty của dòng nấm gây bệnh về phía có vi khuẩn $(\mathrm{mm})$

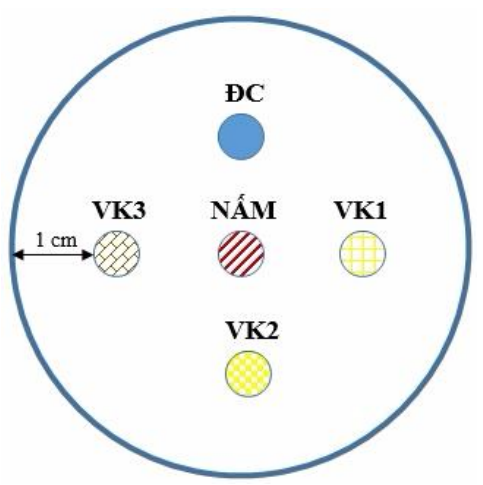

\section{Hình 1. Sơ đồ bố trí khảo sát khả năng đối kháng của vi khuẩn phân lập với nấm Rhizoctonia solani trên môi trường đĩa thạch PDA}

*Ghi chú: ĐC: đối chứng; VK: vi khuẩn; Nấm bệnh đurợc đặt ở tâm đĩa thạch, các chủng vi khuẩn khác nhau và đối chứng được đặt cách thành đĩa $1 \mathrm{~cm}$

2.2.3. Đánh giá hiệu quả đối kháng của 3 dòng vi khuẩn ký hiệu M2, M3 và G5 tuyển chọn đối với nấm $\underline{R}$. solani trong điều kiện in vitro

* Chuẩn bị nấm và vi khuẩn: thực hiện tương tự như mục 2.2.2 
* Bố trí thi nghiệm: Việc khảo sát khả năng đối kháng của 3 dòng vi khuẩn ký hiệu $\mathrm{M} 2, \mathrm{M} 3$ và $\mathrm{G} 5$ với nấm $R$. solani được thực hiện theo phương pháp của Denis and Webster (1971) với 4 phương pháp bố trí thí nghiệm gồm (1) Cả nấm $R$. solani và vi khuẩn được đặt trên môi trường cùng một thời điểm; (2) dùng dịch ngoại bào của vi khuẩn; (3) nấm $R$. solani được đặt trước vi khuẩn 24 giờ và (4) vi khuẩn được đặt trước nấm $R$. solani 24 giờ nhằm tìm ra thời điểm xử lý để các dòng vi khuẩn đối kháng cho hiệu quả cao nhất. Các thí nghiệm về khảo sát khả năng đối kháng ở cả 4 phương pháp bố trí được thực hiện trên môi trường PDA với 6 lần lặp lại cho mỗi chủng vi khuẩn và nấm. Trong đó, mỗi đĩa Petri chứa 2 lặp lại cho mỗi dòng vi khuẩn thử nghiệm và được đặt đối xứng nhau trên đĩa petri và 2 vị trí còn lại trên đĩa là 2 đối chứng với nước cất (Hình 2 ).

- Phuoong pháp bố trí 1: cả nấm R. solani và vi khuẩn được đặt lên trên đĩa môi truờng PDA cùng một thời điểm thí nghiệm: Tiến hành đặt khoanh khuẩn ty có đường kính $6 \mathrm{~mm}$ vào vị trí chính giữa đĩa Petri có chứa môi trường PDA, tiếp theo đặt khoanh giấy lọc có đường kính $1 \mathrm{~cm}$ đã được tẩm huyền phù vi khuẩn với mật số $10^{7} \mathrm{CFU} / \mathrm{mL}$ lên bề mặt môi trường tại 2 vị trí đối xứng nhau tương ứng với 2 lần lặp lại cho 1 dòng vi khuẩn (cách thành đĩa Petri $1 \mathrm{~cm}$ ) và vị trí còn lại đặt mẫu đối chứng với khoanh giấy lọc được tầm nước cất tiệt trùng, để trong 1 phút tiển hành gấp giấy lọc ra khỏi đĩa Petri (Hình 2). Đặt các đĩa chứa mẫu vào tủ ủ ở nhiệt độ $\left(28 \pm 2^{\circ} \mathrm{C}\right)$ và ghi nhận khả năng đối kháng ở các thời điểm $3,5,7$ và 9 ngày sau bố trí thông qua hiệu suất đối kháng của các dòng vi khuẩn được tính theo công thức (1).

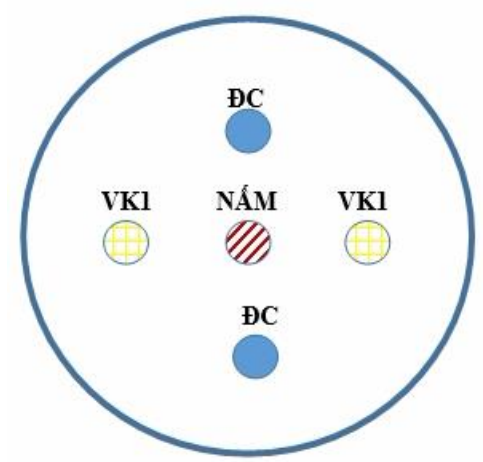

\footnotetext{
Hình 2. So đồ bố trí khảo sát khả năng đối kháng của 3 dòng vi khuẩn triển vọng (M2, M3 và G5) với nấm Rhizoctonia solani trên môi trường PDA
}

*Ghi chú: ĐC: đối chứng; VK: vi khuẩn; Nấm bệnh được đặt ở tâm đĩa thạch, 2 lặp lại của cùng 1 chủng vi khuẩn và đối chứng được đặt cách thành đĩa $1 \mathrm{~cm}$

- Phurong pháp bố trí 2: sủ dụng dịch ngoại bào của vi khuẩn: Khoan 4 giếng đối xứng nhau bằng cách đục lỗ có đường kính $6 \mathrm{~mm}$ trên môi trường thạch $\mathrm{PDA}$ (vị trí đục các giếng cách thành đĩa Petri $1 \mathrm{~cm}$ ). Dùng pipet vô trùng hút $50 \mu \mathrm{L}$ dịch ngoại bào của vi khuẩn từ huyền phù đã được ly tâm trước đó cho vào giếng đã tạo ở 2 vị trí đối xứng nhau tương ứng với 2 lặp lại cho 1 dòng vi khuẩn và 2 vị trí còn lại chứa nước cất tiệt trùng, để yên 5 phút cho dung dịch thấm vào môi trường, sau đó đặt khoanh khuẩn ty có đường kính $6 \mathrm{~mm}$ của dòng nấm $R$. solani gây bệnh đang phát triển tốt vào vị trí chính giữa đĩa Petri (Hình 2$)$, ủ ở nhiệt độ $\left(28 \pm 2^{\circ} \mathrm{C}\right)$ và ghi nhận khả năng đối kháng ở các thời điểm $3,5,7$ và 9 ngày sau bố trí thông qua hiệu suất đối kháng được tính theo công thức (1).

- Phuong pháp bố trí 3: Nấm R. solani được đặt lên trên môi truờng PDA trước vi khuẩn đối kháng 24 giờ: Đặt khoanh khuẩn ty có đường kính 6 $\mathrm{mm}$ của dòng nấm $R$. solani đang phát triển tốt lên trên môi trường nuôi cấy vào vị trí chính giữa đĩa Petri và đặt vào tủ ủ cho nấm phát triển trong 24 giờ. Sau đó, tiến hành cho giấy lọc có đường kính $1 \mathrm{~cm}$ đã được tẩm huyền phù vi khuẩn $\left(10^{7} \mathrm{CFU} / \mathrm{mL}\right)$ lên trên bề mặt đĩa môi trường PDA ở 2 vị trí đối xứng nhau tương ứng với 2 lần lặp lại cho 1 dòng vi khuẩn (cách thành đĩa Petri $1 \mathrm{~cm}$ ), 2 vị trí còn lại chứa mẫu đối chứng. Sau 1 phút để yên và tiến hành gấp giấy lọc ra khỏi đĩa Petri (Hình 2). Các đĩa Petri chứa mẫu được đặt vào tủ ủ ở nhiệt độ $\left(28 \pm 2^{\circ} \mathrm{C}\right)$ và ghi nhận khả năng đối kháng vào các thời điểm $3,5,7$ và 9 ngày sau bố trí thông qua hiệu suất đối kháng của các dòng vi khuẩn được tính theo công thức (1).

- Phuoong pháp bố trí 4: Vi khuẩn đối kháng được đặt lên trên môi truờng PDA truớc nấm 24 giơ: Đặt giấy lọc có đường kính $1 \mathrm{~cm}$ đã được tẩm huyền phù vi khuẩn có nồng độ $10^{7} \mathrm{CFU} / \mathrm{mL}$ lên trên bề mặt đĩa môi trường PDA ở 2 vị trí đối xứng nhau tương ứng với 2 lần lặp lại cho 1 dòng vi khuẩn (cách thành đĩa Petri $1 \mathrm{~cm}$ ), 2 vị trí còn lại chứa mẫu đối chứng. Sau 1 phút để yên và tiến hành gấp giấy lọc ra khỏi đĩa Petri, sau đó đặt vào tủ ủ. Sau 24 giờ, đặt khoanh khuẩn ty có đường kính $6 \mathrm{~mm}$ của dòng nấm $R$. solani đang phát triển tốt lên trên môi trường nuôi cấy vào vị trí chính giữa đĩa Petri (Hình 2$)$. Các đĩa Petri chứa mẫu được đặt vào trong tủ ủ ở nhiệt độ $\left(28 \pm 2^{\circ} \mathrm{C}\right)$ và ghi nhận khả năng đối kháng vào các thời điểm $3,5,7$ và 9 ngày sau bố trí thông qua hiệu suất đối kháng được tính theo công thức (1). 
2.2.4. Địh danh dòng vi khuẩn ký hiệu G5 có khả năng đối kháng tốt với nấm $\underline{R}$. solani gây bệnh chết gục cây con bằng phuơng pháp giải mã trình tụ đoạn gene $16 \mathrm{~S}$ rRNA

Kết hợp các đặc điểm hình thái khuẩn lạc, tế bào và độ tương đồng của dòng vi khuẩn được BLAST để xác định tên loài. Định danh bằng phương pháp giải trình tự đoạn gene $16 \mathrm{~S}$ rRNA với cặp mồi tổng quát 27F/1492R (Lane, 1971) với trình tự nucleotide: 27F: 5' AGA GTT TGA TCC TGG CTC AG 3'; 1492R: 5' GGT TAC CTT GTT ACG ACT T 3'. Sau đó, đoạn gene này được giải mã trình tự ở công ty trách nhiệm hữu hạn Hóa Sinh Phù Sa. Sử dụng chương trình BLAST để so sánh trình tự DNA của chủng vi khuẩn cần định danh với trình tự DNA của bộ gen các loài vi khuẩn có sẵn trong ngân hàng gen thế giới GenBank (https://www.ncbi.nlm. nih.gov/).

\subsubsection{Xư lý số liệu}

Số liệu thí nghiệm được xử lý trên phần mềm Excel và kiểm định thống kê $\mathrm{ANOVA}$, so sánh bằng phép thử Tukey bằng phần mềm Minitab 16.2.

\section{KÊT QUẢ VÀ THẢO LUẬN}

3.1. Phân lập và tuyển chọn một số dòng vi khuẩn từ 4 loại hạt ngũ cốc gồm gạo, bắp, đậu nành và mè

Kết quả phân lập vi khuẩn trên môi trường MRS agar thu được tổng cộng 33 dòng vi khuẩn từ 4 loại hạt ngũ cốc lên men. Trong đó, có 14 dòng vi khuẩn được phân lập từ hạt bắp, chiếm tỉ lệ 42,4\%; 11 dòng vi khuẩn được phân lập từ hạt gạo, chiếm tỉ lệ 33,3\%; 4 dòng vi khuẩn được phân lập từ hạt đậu nành, chiếm tî̉ lệ $12,1 \%$ và 4 dòng vi khuẩn được phân lập từ hạt mè, chiếm 12,1\% (Bảng 1).

Bảng 1. Số lượng vi khuẩn được phân lập từ 4 loại hạt ngũ cốc lên men

\begin{tabular}{cllcc}
\hline STT & Kí hiệu mẫu & Nguồn gốc & Tổng số dòng & Tỉ lệ (\%) \\
\hline 1 & G1, G2, G3, G4, G5, G6, G7, G8, G9, G10 và G11 & Gạo & 11 & 33,3 \\
2 & B1, B2, B3, B4, B5, B6, B7, B8, B9, B10, B11, B12, & Bắp & 14 & 42,4 \\
& B13 và B14 & Đậu nành & 4 & 12,1 \\
3 & Đ1, Đ2, Đ3 và Đ4 & Mè & 4 & 12,1 \\
4 & M1, M2, M3 và M4 & & 33 & 100 \\
\hline \multicolumn{2}{c}{ Tổng cộng }
\end{tabular}

Đặc điểm hình thái khuẩn lạc của 33 dòng vi khuẩn phân lập được trình bày trong Bảng 2 , với các dạng gồm: hình tròn chiếm $87,9 \%$, hình thoi chiếm $9,1 \%$ và khuẩn lạc có hình dạng bất định chiếm $3,0 \%$. Màu sắc khuẩn lạc tương đối đa dạng với các

màu: trắng đục, trắng sữa, vàng và vàng cam, trong đó khuẩn lạc có màu trắng đục chiếm tỉ lệ cao nhất với $63,6 \%$. Độ phẳng khuẩn lạc dao động từ dạng phằng đến mô và kích thước của khuẩn lạc dao động từ 0,5 đến $8,0 \mathrm{~mm}$ (Hình 3 ).

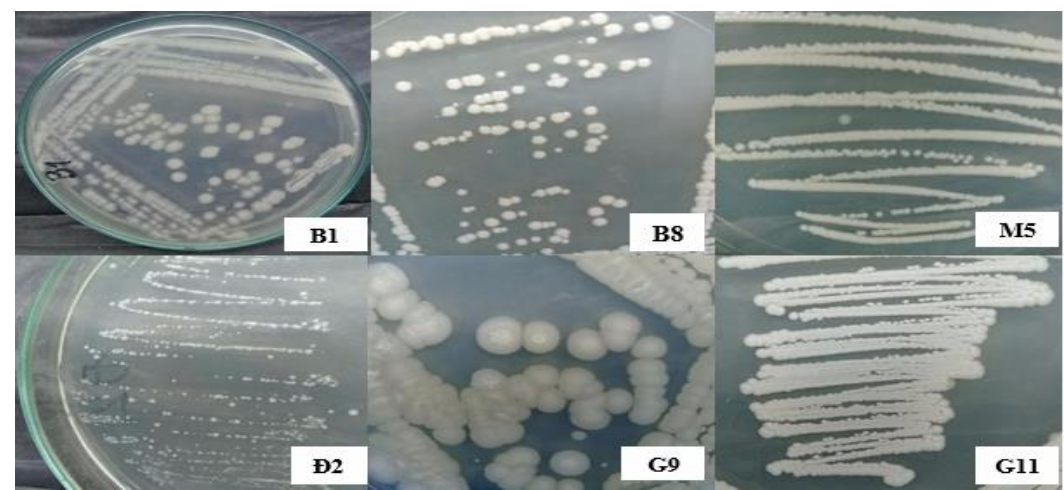

Hình 3. Đặc điểm hình thái khuẩn lạc của một số dòng vi khuẩn trên môi trường TSA

Đặc điểm hình thái tế bào của 33 dòng vi khuẩn phân lập được nhận dạng trên kính hiển vi ở vật kính 100X được trình bày ở Bảng 2 . Kết quả cho thấy có 18 trong tổng số 33 dòng vi khuẩn có tế bào dạng hình cầu (chiếm $54,6 \%$ dòng vi khuẩn phân lập). Ngoài ra, 9 và 5 dòng vi khuẩn trong tổng số 33 dòng phân lập lần lượt có dạng hình trứng và dạng hình que với tỉ lệ lần lượt chiếm $27,3 \%$ và $15,2 \%$. Bên cạnh đó, có 1 dòng vi khuẩn có dạng hình phẩy trong tổng số 33 dòng vi khuẩn phân lập, chiếm tỉ lệ 3,0\% các dòng phân lập (Hình 4). Tất cả các dòng vi khuẩn phân lập đều là vi khuẩn Gram dương, chiếm tỉ lệ $100 \%$. 
Bảng 2. Đặc điểm hình thái khuẩn lạc và tế bào của 33 dòng vi khuẩn phân lập

\begin{tabular}{|c|c|c|c|c|c|c|c|}
\hline \multicolumn{4}{|c|}{ Đăc điểm hình thái khuẩn lạc } & \multicolumn{3}{|c|}{ Đăc điểm hình thái tế bào } & \multirow{2}{*}{ Gram } \\
\hline Đăc điểm & Các loai & Số lương & Tỉ lệ (\%) & Hình dang & Số lương & Tỉ lê (\%) & \\
\hline \multirow{3}{*}{ Hình dạng } & Tròn & 29 & 87,9 & \multirow{3}{*}{ Hình cầu } & \multirow{3}{*}{18} & \multirow{3}{*}{54,55} & \multirow{13}{*}{$\begin{array}{l}100 \% \\
\text { Gram } \\
\text { dương }\end{array}$} \\
\hline & Thoi & 3 & 9,1 & & & & \\
\hline & Bất định & 1 & 3,0 & & & & \\
\hline \multirow{4}{*}{ Màu sắc } & Trắng đục & 21 & 63,6 & \multirow{4}{*}{ Hình trứng } & \multirow{4}{*}{9} & \multirow{4}{*}{27,27} & \\
\hline & Trắng sữa & 1 & 3,0 & & & & \\
\hline & Vàng & 10 & 30,3 & & & & \\
\hline & Vàng cam & 1 & 3,0 & & & & \\
\hline \multirow{2}{*}{ Dạng bìa } & Nguyên & 31 & 93,9 & \multirow{2}{*}{ Hình que } & \multirow{2}{*}{5} & \multirow{2}{*}{15,15} & \\
\hline & Gợn sóng & 2 & 6,1 & & & & \\
\hline \multirow{2}{*}{ Độ nổi } & Phẳng & 5 & 15,2 & \multirow{4}{*}{ Hình phẩy } & \multirow{4}{*}{1} & \multirow{4}{*}{3,03} & \\
\hline & Mô & 28 & 84,9 & & & & \\
\hline \multirow{2}{*}{ Bề mặt } & Khô nhăn & 15 & 45,5 & & & & \\
\hline & Trơn láng & 18 & 54,6 & & & & \\
\hline
\end{tabular}

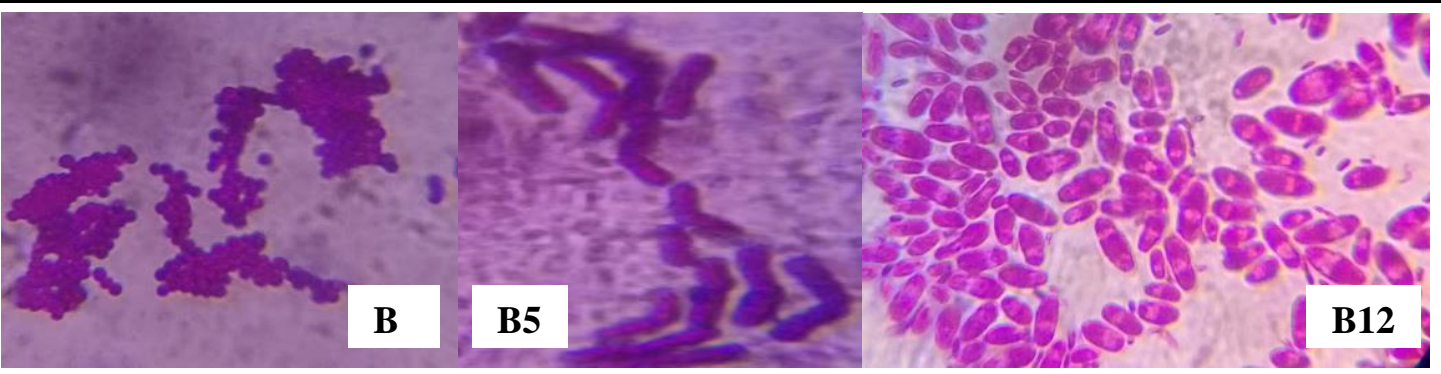

Hình 4. Hình thái tế bào của 3 dòng vi khuẩn đại diện (B3, B5 và B12) được quan sát dưới kính hiện vi quang học với độ phóng đại E100

3.2. Khảo sát khả năng đối kháng với nấm R. solani gây bệnh trên ớt trong điều kiện in vitro của các dòng vi khuẩn phân lập

Kết quả khảo sát khả năng đối kháng với dòng nấm $R$. solani gây bệnh trên ớt trong điều kiện in vitro của các dòng vi khuẩn phân lập được trình bày trong Bảng 3. Kết quả cho thấy có 23 trong tổng số 33 dòng vi khuẩn phân lập có khả năng đối kháng với nấm $R$. solani, với hiệu suất đối kháng (HSĐK) dao động trong khoảng từ $2,59-55,2 \%$ và chiếm tỉ lệ $69,7 \%$ các dòng thử nghiệm. Đồng thời, HSĐK của tất cả 23 dòng này đều có cùng xu hướng giảm dần theo thời gian thí nghiệm. Điều này có thể là do môi trường nuôi cấy để bố trí thí nghiệm là PDA, là môi trường thích hợp cho nấm phát triển tốt, do đó sự sinh trưởng và phát triển của nấm tốt hơn so với vi khuẩn theo thời gian thí nghiệm, vì vậy, hiệu suất đối kháng của các dòng vi khuẩn giảm xuống theo thời gian.
Trong số 23 dòng vi khuẩn thể hiện khả năng đối kháng với dòng nấm gây bệnh $R$. solani, 3 dòng vi khuẩn ký hiệu $\mathrm{M} 2, \mathrm{G} 5$ và $\mathrm{M} 3$ có khả năng duy trì hiệu quả đối kháng cao và khác biệt ý nghĩa thống kê so với các dòng vi khuẩn còn lại qua bốn thời điểm khảo sát. Dòng vi khuẩn $\mathrm{M} 2$ thể hiện khả năng đối kháng tốt nhất và ổn định qua tất cả các thời điểm lấy chỉ tiêu. Hiệu suất đối kháng của dòng vi khuẩn này dao động trong khoảng từ 41,8 đến $55,2 \%$, đạt cao nhất ở thời điểm 3 ngày sau bố trí (NSBT) với $55,2 \%$. Kế đến là dòng vi khuẩn $\mathrm{M} 3$ và G5 với HSĐK đạt lần lượt dao động trong khoảng từ $38-52,2 \%$ và từ $40-50 \%$, cao nhất là $52,2 \%$ (M3) và $50 \%(\mathrm{G} 5)$ vào thời điểm 3 NSBT. Do ba dòng vi khuẩn $\mathrm{M} 2, \mathrm{M} 3$ và $\mathrm{G} 5$ thể hiện khả năng đối kháng tốt nhất với nấm $R$. solani và tương đối ổn định ở tất cả các thời điểm thí nghiệm, vì vậy chúng được chọn để thực hiện các nghiên cứu tiếp theo. 
Bảng 3. Hiệu suất đối kháng của 23 trong tổng số 33 dòng vi khuẩn phân lập với nấm Rhizoctonia solani (04/2019)

\begin{tabular}{|c|c|c|c|c|c|}
\hline \multirow{2}{*}{ STT } & \multirow{2}{*}{ Nghiệm thức } & \multicolumn{4}{|c|}{ Hiệu suất đối kháng (\%) } \\
\hline & & 3 NSBT & 5 NSBT & 7 NSBT & 9 NSBT \\
\hline 1 & B9 & $43,6 \mathrm{~d}^{\mathrm{e}}$ & $0,0^{\mathrm{k}}$ & $0,0^{\mathrm{i}}$ & $\overline{0,0^{1}}$ \\
\hline 2 & B12 & $41,6^{\mathrm{e}}$ & $36,7^{\mathrm{e}}$ & $27,8^{\mathrm{e}}$ & $27,4^{\mathrm{g}}$ \\
\hline 3 & B13 & $41,5^{\mathrm{e}}$ & $32,0^{\mathrm{fg}}$ & $32,2^{\mathrm{d}}$ & $29,3^{\mathrm{fg}}$ \\
\hline 4 & B14 & $46,6^{c}$ & $41,5^{\mathrm{d}}$ & $43,3^{\mathrm{bc}}$ & $27,9^{\mathrm{g}}$ \\
\hline 5 & G1 & $28,7^{\mathrm{h}}$ & $20,9^{\mathrm{i}}$ & $22,6^{\mathrm{f}}$ & $12,1^{\mathrm{j}}$ \\
\hline 6 & $\mathrm{G} 2$ & $14,8^{1}$ & $19,5^{\mathrm{i}}$ & $6,5^{\mathrm{h}}$ & $2,6^{1}$ \\
\hline 7 & G3 & $35,3^{\mathrm{fg}}$ & $32,5^{\mathrm{f}}$ & $29,8^{\text {de }}$ & $31,5^{\mathrm{f}}$ \\
\hline 8 & G4 & $27,9^{\mathrm{h}}$ & $18,9^{\mathrm{i}}$ & $17,9^{\mathrm{g}}$ & $7,1^{\mathrm{k}}$ \\
\hline 9 & G5 & $50,0^{\mathrm{b}}$ & $44,89^{\mathrm{c}}$ & $43,7^{b}$ & $40,0^{\mathrm{ab}}$ \\
\hline 10 & G6 & $45,0^{\mathrm{cd}}$ & $43,2^{\text {cd }}$ & $40,5^{\mathrm{c}}$ & $37,9^{\mathrm{bc}}$ \\
\hline 11 & G7 & $37,2^{\mathrm{f}}$ & $33,1^{\mathrm{f}}$ & $40,7^{\mathrm{c}}$ & $34,8^{\mathrm{de}}$ \\
\hline 12 & G8 & $37,9^{f}$ & $32,6^{\mathrm{f}}$ & $31,8^{\mathrm{d}}$ & $32,1^{\text {ef }}$ \\
\hline 13 & G9 & $36,9^{\mathrm{fg}}$ & $32,3^{\mathrm{f}}$ & $30,9^{\mathrm{d}}$ & $28,5^{\mathrm{g}}$ \\
\hline 14 & G10 & $34,1^{\mathrm{g}}$ & $36,8^{\mathrm{e}}$ & $32,3^{\mathrm{d}}$ & $35,3^{\text {cd }}$ \\
\hline 15 & G11 & $27,3^{\mathrm{h}}$ & $24,3^{\mathrm{h}}$ & $31,4^{\mathrm{d}}$ & $21,5^{\mathrm{h}}$ \\
\hline 16 & M1 & $23,8^{\mathrm{i}}$ & $29,6^{\mathrm{g}}$ & $20,6^{\mathrm{f}}$ & $15,3^{\mathrm{i}}$ \\
\hline 17 & M2 & $55,2^{\mathrm{a}}$ & $53,9^{\mathrm{a}}$ & $52,1^{\mathrm{a}}$ & $41,8^{\mathrm{a}}$ \\
\hline 18 & M3 & $52,2^{\mathrm{b}}$ & $50,1^{\mathrm{b}}$ & $45,2^{\mathrm{b}}$ & $38,0^{\mathrm{bc}}$ \\
\hline 19 & M4 & $6,7^{\mathrm{m}}$ & $10,2^{\mathrm{j}}$ & $4,2^{\mathrm{h}}$ & $0,0^{1}$ \\
\hline 20 & $Đ 1$ & $22,5^{\mathrm{ij}}$ & $0,0^{\mathrm{k}}$ & $0,0^{\mathrm{i}}$ & $0,0^{1}$ \\
\hline 21 & Đ2 & $19,3^{\mathrm{k}}$ & $0,0^{\mathrm{k}}$ & $0,0^{\mathrm{i}}$ & $0,0^{1}$ \\
\hline 22 & Đ3 & $20,5^{\mathrm{jk}}$ & $0,0^{\mathrm{k}}$ & $0,0^{\mathrm{i}}$ & $0,0^{1}$ \\
\hline 23 & Đ4 & $23,3^{\mathrm{i}}$ & $0,0^{\mathrm{k}}$ & $0,0^{\mathrm{i}}$ & $0,0^{1}$ \\
\hline & $\overline{V(\%)}$ & 37,25 & 42,25 & 48,56 & 49,84 \\
\hline & $\mathrm{F}$ & * & $*$ & $*$ & * \\
\hline
\end{tabular}

*Ghi chú: NSBT: ngày sau bố trí; B: bắp; G: gạo; Đ: đậu nành; M: mè; Trong cùng một cột, các chũ số có mẫu tư theo sau giống nhau thi không khác biệt có ý nghĩa thống kê ơ mức 5\% (*) theo phép thử Tukey

3.3. Đánh giá hiệu quả đối kháng của 3 dòng vi khuẩn ký hiệu M2, M3 và G5 đối với nấm R. solani trong điều kiện in vitro với 4 phương pháp bố trí khác nhau

3.3.1. Phưong pháp bố trí 1: nấm $\underline{R}$. solani và vi khuẩn được đặt lên trên môi trường PDA cùng một thời điểm

Kết quả khảo sát khả năng đối kháng của 3 dòng vi khuẩn $\mathrm{M} 2, \mathrm{M} 3$ và $\mathrm{G} 5$ với nấm Rhizoctonia solani thông qua hiệu suất đối kháng khi nấm và vi khuẩn được đặt lên môi trường cùng một thời điểm được trình bày trong Bảng 4 . Nhìn chung, ba dòng vi khuẩn đều thể hiện khả năng đối kháng cao qua các thời điểm khảo sát. HSĐK của 2 dòng vi khuẩn M3 và $\mathrm{G} 5$ có xu hướng tăng theo thời gian thí nghiệm, trong khi dòng vi khuẩn M2 lại giảm xuống. Bên cạnh đó, dòng vi khuẩn G5 luôn duy trì hiệu suất đối kháng cao nhất qua mọi thời điểm, đặc biệt là ở 9 NSBT dòng vi khuẩn này có HSĐK là $59,6 \%$, khác biệt ý nghĩa thống kê ở mức 5\% so với 2 dòng vi khuẩn còn lại. Dòng vi khuẩn $\mathrm{M} 3$ cho $\mathrm{HSĐK}$ với nấm bệnh cao nhất ở 9 ngày sau khi cấy và đạt giá trị 52, 8\%. Trong khi dòng vi khuẩn M2 đạt HSĐK thấp nhất so với hai dòng vi khuẩn $\mathrm{G} 5$ và $\mathrm{M} 3$. HSĐK cao nhất của của dòng vi khuẩn $\mathrm{M} 2$ đạt $44,3 \%$ vào thời điểm 5 ngày sau bố trí. Như vậy, khi đặt cùng lúc vi khuẩn và nấm gây bệnh lên trên môi trường $\mathrm{PDA}$, dòng vi khuẩn $\mathrm{G} 5$ và $\mathrm{M} 3$ thể hiện khả năng đối kháng tốt với dòng nấm $R$. solani gây bệnh trên ớt. 
Bảng 4. Hiệu suất đối kháng của 3 dòng vi khuẩn với nấm $R$. solani khi được chủng cùng một thời điểm thí nghiệm

\begin{tabular}{ccrrrr}
\hline \multirow{2}{*}{ STT } & \multirow{2}{*}{ Nghiệm thức } & \multicolumn{4}{c}{ Hiệu suất đối kháng (\%) } \\
\cline { 3 - 6 } & M2 & 3 NSBT & 5 NSBT & 7 NSBT & 9 NSBT \\
\hline 1 & M3 & $42,3^{\mathrm{b}}$ & $44,4^{\mathrm{b}}$ & $41,5^{\mathrm{c}}$ & $39,4^{\mathrm{c}}$ \\
2 & G5 & $39,7^{\mathrm{c}}$ & $41,8^{\mathrm{c}}$ & $49,0^{\mathrm{b}}$ & $52,8^{\mathrm{b}}$ \\
3 & $49,9^{\mathrm{a}}$ & $50,2^{\mathrm{a}}$ & $54,2^{\mathrm{a}}$ & $59,6^{\mathrm{a}}$ \\
\hline \multicolumn{2}{c}{ CV(\%) } & 10,82 & 8,63 & 11,64 & 17,35 \\
\multicolumn{2}{c}{ F } & $*$ & $*$ & $*$ & $*$ \\
\hline
\end{tabular}

*Ghi chú: NSBT: Ngày sau bố trí; M: Mè; G: gạo; Trong cùng một cột, các chũ số có mẫu tụ theo sau giống nhau thì không khác biệt có ý nghĩa thống kê ở mức 5\% (*) theo phép thủ Tukey

\subsubsection{Phuong pháp bố trí 2: bố trí bằng dịch} ngoại bào vi khuẩn

Kết quả khảo sát khả năng đối kháng của 3 dòng vi khuẩn $\mathrm{M} 2, \mathrm{M} 3$ và $\mathrm{G} 5$ với dòng nấm $R$. solani thông qua hiệu suất đối kháng khi sử dụng dịch ngoại để bố trí được trình bày trong Bảng 5 .

HSĐK của các dòng vi khuẩn có xu hướng giảm dần theo thời gian. Ở thời điểm 3 NSBT, HSĐK của dòng M2 đạt cao nhất với 41,26\%, khác biệt thống kê ở mức ý nghĩa $5 \%$ so với 2 dòng vi khuẩn còn lại. Sang các thời điểm 5,7 và 9 NSBT, 2 dòng vi khuẩn M2 và G5 có HSĐK tương đương nhau và khác biệt so với dòng $\mathrm{M} 3$. Cụ thể 2 dòng này lần lượt đạt $43,1 \%(\mathrm{M} 2), 37,8 \%(\mathrm{G} 5)$ ở thời điểm $5 \mathrm{NSBT}$ và 30,8\% (M2), 32,4\% (G5) ở thời điểm 9 NSBT. Dòng vi khuẩn M3 luôn đạt HSĐK thấp hơn so với 2 dòng còn lại qua tất cả các thời điểm khảo sát và khác biệt ý nghĩa thống kê $(\mathrm{p}<0,05)$.

Bảng 5. Hiệu suất đối kháng của 3 dòng vi khuẩn với nấm $R$. solani khi được bố trí bằng dịch ngoại bào của vi khuẩn

\begin{tabular}{ccrrrr}
\hline \multirow{2}{*}{ STT } & \multirow{2}{*}{ Nghiệm thức } & \multicolumn{4}{c}{ Hiệu suất đối kháng (\%) } \\
\cline { 2 - 6 } & M2 & 3 NSBT & 5 NSBT & 7 NSBT & 9 NSBT \\
\hline 1 & M3 & $41,3^{\mathrm{a}}$ & $43,5^{\mathrm{a}}$ & $36,1^{\mathrm{a}}$ & $30,8^{\mathrm{a}}$ \\
2 & G5 & $37,3^{\mathrm{b}}$ & $38,9^{\mathrm{b}}$ & $31,6^{\mathrm{b}}$ & $28,3^{\mathrm{b}}$ \\
3 & $38,1^{\mathrm{b}}$ & $42,6^{\mathrm{a}}$ & $37,8^{\mathrm{a}}$ & $32,4^{\mathrm{a}}$ \\
\hline \multicolumn{2}{c}{ CV(\%) } & 5,74 & 5,85 & 8,60 & 6,97 \\
\multicolumn{2}{c}{ F } & $*$ & $*$ & $*$ & $*$ \\
\hline
\end{tabular}

*Ghi chú: NSBT: Ngày sau bố trí; M: Mè; G: gạo; Trong cùng một cốt, các chũ số có mẫu tụ theo sau giống nhau thi không khác biệt có ý nghĩa thống kê ở múc 5\% theo phép thủ Tukey

Hiệu quả ức chế khuẩn ty nấm do dịch ngoại bào của các dòng vi khuẩn giảm dần theo thời gian ghi nhận chỉ tiêu có thể là do môi trường nuôi cấy để bố trí thí nghiệm là $\mathrm{PDA}$, là môi trường thích hợp cho nấm phát triển tốt, bên cạnh đó có thể các hợp chất có hoạt tính sinh học do 3 dòng vi khuẩn này tiết ra để ức chế sự phát triển của nấm $R$. solani thuộc nhóm dễ bay hơi và không được cung cấp liên tục bởi nguồn vi khuẩn sống nên tính bền vững về khả năng đối kháng với nấm gây bệnh của dịch ngoại bào do vi khuẩn tiết ra là không ổn định theo thời gian thí nghiệm như theo kết quả nghiên cứu của Pal and Gardener (2006) và Chi et al. (2012) cho thấy nhiều loại kháng sinh được tổng hợp bởi vi khuẩn nhóm Bacillus sp. gồm những chất có hoạt tính sinh học như bacillomycin, fengycin, mycosubtilin, zwittermicin và acetylbuanediol,... có hiệu quả ngăn chặn và ức chế sự phát triển của các dòng nấm gây bệnh cây trồng là những hợp chất hữu cơ rất dễ bay hơi. Như vậy, thí nghiệm sử dụng dịch ngoại bào cho thấy dòng vi khuẩn $\mathrm{M} 2$ và $\mathrm{G} 5$ có hiệu quả tốt hơn dòng $\mathrm{M} 3$ trong việc đối kháng với nấm $R$. solani gây bệnh trên ớt.

3.3.3. Phuơng pháp bố trí 3: nấm $\underline{R}$. solani được đặt truớc vi khuấn 24 giờ

Kết quả khảo sát khả năng đối kháng với nấm $R$. solani của 3 dòng vi khuẩn ký hiệu $\mathrm{M} 2, \mathrm{M} 3$ và $\mathrm{G} 5$ thông qua hiệu suất đối kháng ở điề̀u kiện thí nghiệm nấm được đặt trước ba dòng vi khuẩn 24 giờ được trình bày trong Bảng 7 . Kết quả cho thấy hai dòng vi khuẩn $\mathrm{M} 2$ và $\mathrm{G} 5$ có $\mathrm{HS} Đ K$ giảm theo thời gian, trong khi đó dòng vi khuẩn M3 có HSĐK tăng lên.

Ở thời điểm $3 \mathrm{NSBT}$, dòng M2 có HSĐK cao nhất với 29,03\%, thấp nhất là dòng G5 với $24,11 \%$. Trong khi dòng vi khuẩn M3 cho HSĐK là 26,57 \%. Cả ba nghiệm thức đặt 3 dòng vi khuẩn này khác biệt ý nghĩa thống kê $(\mathrm{p}<0,05)$ khi so sánh với nhau. 
Sang thời điểm $5 \mathrm{NSBT}$, cả 2 dòng $\mathrm{M} 2$ và $\mathrm{M} 3$ có HSĐK cao tương đương nhau và cao hơn dòng G5 ( $\mathrm{p}<0,05)$. Đến thời điểm 9 NSBT, thứ bậc xếp hạng khả năng đối kháng tương tự như với thời điểm 5 NSBT với M2 đạt 25,16\% tương đương với M3 $(25,51 \%)$ và cao hơn $\mathrm{G} 5$ với HSĐK là $22,3 \%$.

Bảng 7. Hiệu suất đối kháng với nấm Rhizoctonia solani của 3 dòng vi khuẩn tuyển chọn trong điều kiện nấm được đặt trước vi khuẩn 24 giò̀

\begin{tabular}{ccrrrr}
\hline \multirow{2}{*}{ STT } & \multirow{2}{*}{ Nghiệm thức } & \multicolumn{4}{c}{ Hiệu suất đối kháng (\%) } \\
\cline { 2 - 6 } & M2 & 3 NSBT & 5 NSBT & 7 NSBT & 9 NS \\
\hline 1 & M3 & $29,0 \mathrm{a}$ & $27,2 \mathrm{a}$ & $26,3 \mathrm{~b}$ & $25,2 \mathrm{a}$ \\
2 & G5 & $26,6 \mathrm{~b}$ & $27,6 \mathrm{a}$ & $30,6 \mathrm{a}$ & $25,5 \mathrm{a}$ \\
3 & $24,1 \mathrm{c}$ & $24,2 \mathrm{~b}$ & $21,9 \mathrm{c}$ & $22,3 \mathrm{c}$ \\
\hline \multicolumn{2}{c}{ CV(\%) } & 9,20 & 8,00 & 14,96 & 7,43 \\
& F & $*$ & $*$ & $*$ & $*$ \\
\hline
\end{tabular}

*Ghi chú: NSBT: Ngày sau bố trí; M: Mè; G: gạo; Trong cùng một cột, các chũ số có mẫu tư theo sau giống nhau thì không khác biệt có ý nghĩa thống kê ở mức 5\% theo phép thủ Tukey

Nhìn chung, ở cả 3 dòng vi khuẩn đều thể hiện khả năng đối kháng qua các thời điểm khảo sát. Như vậy, ở điều kiện thí nghiệm dòng nấm $R$. solani được đặt trước vi khuẩn làm cho HSĐK của 3 dòng vi khuẩn giảm đi rất nhiều so với khi đặt cả nầm và vi khuẩn cùng thời điểm cũng như phương pháp bố trí bằng các sử dụng dịch ngoại bào của vi khuẩn. Điều này có thể giải thích là do môi trường bố trí thí nghiệm là $\mathrm{PDA}$ thích hợp cho nấm phát triển và tiết ra các hợp chất có khả năng ức chế hoặc làm hạn chế hoạt động của các dòng vi khuẩn đối kháng.
3.3.4. Phuơng pháp bố trí 4: vi khuẩn được đặt trước nấm $\underline{R}$ solani 24 giò

Kết quả khảo sát khả năng đối kháng với nấm $R$. solani của 3 dòng vi khuẩn ký hiệu $\mathrm{M} 2, \mathrm{M} 3$ và $\mathrm{G} 5$ thông qua hiệu suất đối kháng khi vi khuẩn được đặt trước nấm 24 giờ được trình bày trong Bảng 8 . Nhìn chung, ở cả 3 dòng vi khuẩn thử nghiệm đều có hiệu suất đối kháng cao nhất khi so sánh 4 phương pháp bố trí thí nghiệm với nhau.

Bảng 8. Hiệu suất đối kháng với nấm $R$. solani của 3 dòng vi khuẩn ở điều kiện vi khuẩn chủng trước nấm 24 giờ

\begin{tabular}{ccrrrr}
\hline \multirow{2}{*}{ STT } & \multirow{2}{*}{ Nghiệm thức } & \multicolumn{4}{c}{ Hiệu suất đối kháng (\%) } \\
\cline { 2 - 6 } & M2 & 3 NSBT & 5 NSBT & 7 NSBT & 9 NSBT \\
\hline 1 & M3 & $49,51^{\mathrm{c}}$ & $49,95^{\mathrm{c}}$ & $48,90^{\mathrm{c}}$ & $39,34^{\mathrm{c}}$ \\
2 & $55,29^{\mathrm{b}}$ & $54,94^{\mathrm{b}}$ & $51,77^{\mathrm{b}}$ & $52,36^{\mathrm{b}}$ \\
3 & G5 & $59,48^{\mathrm{a}}$ & $66,21^{\mathrm{a}}$ & $57,43^{\mathrm{a}}$ & $60,96^{\mathrm{a}}$ \\
\hline \multicolumn{2}{c}{ CV(\%) } & 7,99 & 12,56 & 7,55 & 18,21 \\
\multicolumn{2}{c}{ F } & $*$ & $*$ & $*$ & $*$ \\
\hline
\end{tabular}

*Ghi chú: NSBT: Ngày sau bố trí; M: Mè; G: gạo; Trong cùng một cột, các chũ số có mẫu tụ theo sau giống nhau thì không khác biệt có ý nghĩa thống kê ở mức 5\% theo phép thư Tukey

Hai dòng vi khuẩn $\mathrm{M} 2$ và $\mathrm{M} 3$ có $\mathrm{HSĐK}$ giảm dần theo thời gian thí nghiệm trong khi dòng vi khuẩn G5 có HSĐK tăng dần. Trong tất cả các thời điểm ghi nhận, hiệu suất đối kháng của dòng G5 luôn cao nhất, kế đển là HSĐK của dòng $\mathrm{M} 3$ và thấp nhất là dòng vi khuẩn $\mathrm{M} 2$, khác biệt ý nghĩa thống kê $(p<0,05)$ khi so sánh với nhau. Dòng vi khuẩn G5 cho HSĐK với dòng nấm gây bệnh cao nhất với $66,21 \%$, trong khi đó hai dòng vi khuẩn $\mathrm{M} 2$ và $\mathrm{M} 3$ cho HSĐK cao nhất và lần lượt đạt 49,95 và $54,9 \%$ vào thời điểm 5 NSBT.

Kết quả nghiên cứu cho thấy cả 3 dòng vi khuẩn ký hiệu $\mathrm{M} 2, \mathrm{M} 3$ và $\mathrm{G} 5$ có khả năng đối kháng cao với nấm $R$. solani gây bệnh hại trên ớt. Bên cạnh đó, khuẩn ty của nấm và khuẩn lạc vi khuẩn $\mathrm{M} 2$ không chạm vào nhau (Hình 5), chứng tỏ dòng M2 có khả năng tiết ra một số enzyme hoặc chất kháng nấm có khả năng ức chế mầm bệnh. Điều này hoàn toàn phù hợp, bởi các dòng vi khuẩn được phân lập từ việc lên men có khả năng tiết ra hoạt chất sinh học bacteriocin có thể tiêu diệt các vi sinh vật khác do sự hình thành các kênh làm thay đổi tính thẩm thấu của màng tế bào và tấn công peptidoglycan để làm suy yếu thành tế bào (Nguyễn Thị Hoài Hà và ctv., 2002). Theo Nguyễn Thị Thu Nga (2003), trong các vi sinh vật có lợi trong tự nhiên như nấm, xạ khuẩn, virus thì vi khuẩn đối kháng giữ vai trò vô cùng quan trọng, chúng tồn tại khắp nơi và trên bề mặt cây trồng, chúng có khả năng hạn chế những vi sinh vật khác bằng các cơ chế như: tiết ra chất kháng sinh, 
cạnh tranh về dinh dưỡng, nơi ở ngoài ra còn hạ chế sự phát triển của nhóm vi sinh vật khác góp phần tạo sự cân bằng sinh thái trong tự nhiên. Một số kết quả nghiên cứu ghi nhận vi khuẩn Bacillus cereus có khả năng tiết chitinase phân hủy vách tế bào nấm $R$. solani và kiểm soát bệnh do nấm Verticillium dahliae và Plectosporium tabacinum gây ra (Berg and Hallmann, 2006).

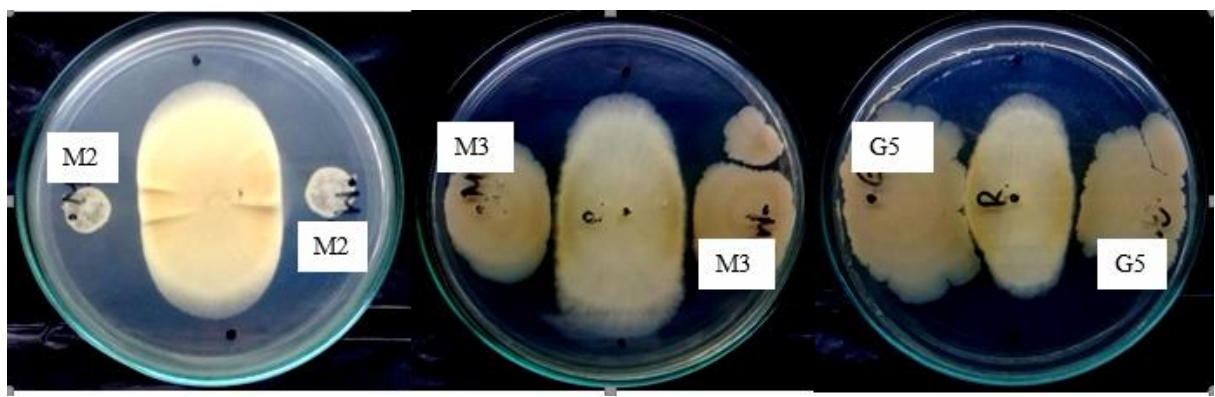

Hình 5. Hiệu quả ức chế của dòng vi khuẩn M2, M3 và G5 với nấm Rhizoctonia solani ở thời điểm 5 ngày sau bố trí

Kết quả khảo sát hiệu quả đối kháng thông qua chỉ số hiệu suất đối kháng cho thấy dòng vi khuẩn G5 có hiệu suất đối kháng với nấm $R$. solani cao hơn và khác biệt thống kê ở mức ý nghĩa $5 \%$ so với hai dòng vi khuẩn còn lại. Điều này cho thấy hiệu quả ức chế khuẩn ty nấm của dòng vi khuẩn G5 được thực hiện bởi nhiều cơ chế khác nhau và sử dụng cơ chế cạnh tranh nhiều hơn cơ chế tiết kháng sinh. Hình ảnh ghi nhận từ thí nghiệm (Hình 5) cho thấy chủng vi khuẩn G5 phát triển lan rộng về phía khuẩn ty của nấm bệnh làm sợi nấm không thể vượt qua được. Sharma (2006) cũng nhận định rằng khi mật số của vi khuẩn phát triển vượt trội sẽ thể hiện khả năng cạnh tranh dinh dưỡng, cạnh tranh nguồn sắt, không gian sống hay dựa vào cơ chế tiết enzyme để phân giải vách tế bào sợi nấm của mầm bệnh. Sự canh tranh này có thể diễn ra theo nhiều cách như: gây ra những sự biến đổi bất thường trong hình thành bào tử, làm trương phòng sợi nấm, phá hủy hoặc làm hư hại các cấu trúc của sợi nấm hay tiết ra các enzyme phân giải sợi nấm. Khi nguồn dinh dưỡng trên môi trường không còn hoặc giảm xuống mức tối thiểu, sự phát triển của nấm sẽ bị cản trở.

Tóm lại, dòng vi khuẩn G5 thể hiện khả năng đối kháng tốt nhất với nấm $R$. solani ở điều kiện vi khuẩn được chủng trước nấm sau 24 giờ. Do đó, có thể sử dụng dòng vi khuẩn G5 trong phòng trừ đối với nấm $R$. solani gây bệnh chết cây con trên ớt bằng cách phun ngừa trước khi nấm bệnh xuất hiện. Như vậy, kết quả này cho thấy việc sử dụng 3 dòng vi khuẩn này để phòng ngừa sự phát triển của nấm $R$. solani gây bệnh cho cây trồng ở điều kiện thực tế đồng ruộng là rất cần thiết và có hiệu quả cao.

\section{4. Định danh dòng vi khuẩn ký hiệu $\mathrm{G} 5$ có khả} năng đối kháng nấm gây bệnh cây trồng cao nhất

Trong số 33 dòng vi khuẩn phân lập và khảo sát khả năng đối kháng với nấm $R$. solani cho thấy dòng vi khuẩn ký hiệu G5 được phân lập từ hạt gạo thể hiện khả năng đối kháng cao thông qua chỉ số hiệu suất đối kháng. Do đó, dòng vi khuẩn G5 được chọn để định danh.

\section{Bảng 9. Kết quả định danh dòng vi khuẩn phân lập G5}

\begin{tabular}{cccccc}
\hline \multirow{2}{*}{ Dòng } & \multirow{2}{*}{ Nguồn gốc } & $\begin{array}{c}\text { Độ tương } \\
\text { đồng(\%) }\end{array}$ & \multicolumn{2}{c}{ Các dòng vi khuẩn trên cơ sở dữ liệu } & \multirow{2}{*}{ Định danh } \\
\cline { 4 - 5 } & Tên loài vi khuẩn & Số đăng ký & \\
\hline \multirow{2}{*}{ G5 } & Hạt gạo & $99,6 \%$ & $\begin{array}{c}\text { Bacillus velezensis } \\
\text { FZB42 }\end{array}$ & NR 075005.2 & $\begin{array}{c}\text { Bacillus } \\
\text { velezensis } \text { G5 }\end{array}$ \\
\hline
\end{tabular}

Dòng vi khuẩn G5 có hình thái khuẩn lạc bất định, màu vàng, phẳng, rìa nguyên, bề mặt trơn láng, Gram dương và tế bào có hình cầu. Bên cạnh đó kết quả trình tự đoạn gen của dòng vi khuẩn G5 tương đồng với đoạn gen $16 \mathrm{~S}-\mathrm{rDNA}$ của loài vi khuẩn Bacillus velezensis với tính đồng hình là $99,6 \%$. Như vậy, dòng vi khuẩn có khả năng đối kháng tốt với nấm khảo sát thuộc chi Bacillus và được định danh là Bacillus velezensis G5, xếp theo bậc phân loại sinh vật từ giới Bacteria; ngành Firmicutes; lớp
Bacilli; bộ Bacillales; họ Bacillaceae đến chi Bacillus. Các thông tin về kết quả định danh dòng vi khuẩn này được trình bày trong Bảng 9 .

\section{KẾT LUẬN VÀ ĐỀ NGH!}

\subsection{Kết luận}

Ba mươi ba dòng vi khuẩn đã được phân lập từ các loại hạt ngũ cốc lên men gồm bắp, gạo, mè và đậu nành trên môi trường MRS agar. 
Thông qua chỉ số hiệu suất đối kháng và kết quả khảo sát khả năng đối kháng có thể thấy dòng vi khuẩn G5 đạt hiệu quả đối kháng cao nhất với nấm $R$. solani ở điều kiện thí nghiệm vi khuẩn được chủng trước nấm 24 giờ khi so với 3 điều kiện thí nghiệm còn lại.

Kết quả giải mã trình tự đoạn gen $16 \mathrm{~S}$ rDNA của dòng vi khuẩn G5 được định danh là Bacillus velezensis G5.

\section{2. Đề nghị}

Tiếp tục nghiên cứu thêm ảnh hưởng của một số yếu tố môi trường lên khả năng đối kháng với nấm $R$. solani, trong điều kiện phòng thí nghiệm đối với dòng vi khuẩn Bacillus velezensis G5. Nghiên cứu cơ chế đối kháng với nấm bệnh cây trồng của dòng vi khuẩn G5. Khảo sát khả năng đối kháng của dòng vi khuẩn G5 trong điều kiện nhà lưới trong việc phòng trừ bệnh chết gục cây con trên ớt.

\section{TÀI LIẸU THAM KHẢO}

Agrios, G.N. (2005). Plant Pathology, Fifth Edition. Elsevier. Amsterdam, 948 pages.

Berg, G. \& Hallmann, J. (2006). Control of Plant Pathogenic Fungi with Bacterial Endophytes. In: Schulz, B., Boyle, C. and Sieber, T. (Eds.). Microbial Root Endophytes. Springer-Verlag, Berlin Heidelberg, pp, 53-69.

Islam, M.R., Jeong, Y.T., Lee, Y.S., \& Song, C. (2012). Isolation and Identification of Antifungal Compounds from Bacillus subtilis C9 Inhibiting the Growth of Plant Pathogenic

Fungi. Mycobiology, 40, 59 - 66.

Dennis, C., \& Webster, J. (1971). Antagonistic properties of species-groups of Trichoderma: I. Production of non-volatile antibiotics. Transactions of The British Mycological Society, 57, 25-39.

Hoben, H. J., \& Somasegaran, P. (1982). Comparison of the pour, spread, and drop plate methods for enumeration of Rhizobium spp. in inoculants made from presterilized peat. Applied and environmental microbiology, 44(5), 1246-1247.

John, G.H. (1994). Bergey's manual of determinative bacteriology, Ninth Edition. Lippincott Williams and Wilkin. Baltimore, 744 pages.

Lane, D.J.. (1991). 16S/23S rRNA sequencing. In: Stackebrandt, E. and Goodfellow, M. (Eds.). Nucleic acid techniques in bacterial systematics. John Wiley and Sons. New York: pp, 115-175.

Lưu Thế Hùng (2014). Khảo sát khả năng đối kháng của các chủng vi khuẩn Bacillus spp. đối vớ $i$ nấm gây bệnh đốm vằn hại lúa (Rhizoctonia solani Kuhn) và khả năng phòng trị trong đièu kiện nhà luoói. Luận văn cao học. Trường Đại học Cần Thơ.

Mai Thị Phương Anh (1996). Rau và trồng rau. Nhà xuất bản Nông nghiệp Hà Nội. Hà Nội, 254 trang.

Ngô Thị Kim Ngân (2014). Khảo sát đặc tính của các chủng xạ khuẩn có khả năng đối kháng với nấm Rhizoctonia solani Kuhn gây bệnh đốm vằn trên lúa. Luận văn cao học. Trường Đại học Cần Thơ.

Nguyễn Thị Hoài Hà, Phạm Văn Ty \& Nguyễn Thị Kim Quy (2002). Nghiên cứu khả năng sinh tồng hợp bacteriocin của loài Lactobacillus plantarum L24. Tạp chí Di truyền học và úng dụng, 5, 47-52.

Nguyễn Thị Thu Nga (2003). Khảo sát khả năng đối kháng của vi khuẩn đối với nấm và tìm môi trường nhân nuôi thích hợp. Luận văn cao học. Trường Đại học Cần Thơ.

Pal, K.K. \& Gardener, B.M. (2006). Biological control of plant pathogens. Plant Health Instructor, 1, 1-25.

Pernezny, K. \& Momol, T. (2006). Florida Plant Disease Management Guide: Pepper, accessed on 5 July 2020. Available from https://ufdcimages.uflib.ufl.edu/UF/00/05/38/71/ 00017/PG05200.pdf

Phạm Văn Biên, Bùi Cách Tuyến \& Nguyễn Mạnh Chinh (2005). Cẩm nang thuốc bảo vệ thực vật 2005. Nhà xuất bản Nông nghiệp Tp.HCM. Thành phố Hồ Chí Minh, 624 trang.

Sharma, P.D. (2006). Plant Pathology. Alpha Science International Ltd. Oxford, 550 pages.

Silva, H.S., Romeiro, R.S., Filho, R.C., Pereira, J.L., Mizubuti, E.S., \& Mounteer, A. (2004). Induction of systemic resistance by Bacillus cereus against tomato foliar diseases under field conditions. Journal of Phytopathology, 152, 371-375.

Tohno, M., Kitahara, M., Inoue, H., Uegaki, R., Irisawa, T., Ohkuma, M., \& Tajima, K. (2013). Weissella oryzae sp. nov., isolated from fermented rice grains. International journal of systematic and evolutionary microbiology, 63(4), 1417-1420.

Trần Ánh Lụa (2016). Khảo sát khả năng kich kháng lư dẫn của vi khuẩn Bacillus spp. đối với bệnh cháy lá lúa do nấm Pyricularia oryzae cavara trong điều kiện nhà lioói. Luận văn cao học. Trường Đại học Cần Thơ.

Võ Thị Lệ Trinh và Nguyễn Khởi Nghĩa (2018). Phân lập, tuyển chọn và định danh một số dòng vi khuẩn có khả năng làm giảm màu mật rỉ đường sau lên men cồn từ một số hạt ngũ cốc. Tạp chi Khoa học Trưòng Đại học Cần Thơ, 9a, 37-45. 